\title{
Traumatic Injury from a Tooth Brush: An Unusual Hazard of Oral Hygiene
}

\author{
Sonia Goyal, Suhas Godhi, Sandeep Goyal
}

\section{ABSTRACT}

We present a case of a 6 year old boy with a history of soft tissue injury caused by a toothbrush, the snapped head of which lodged into the medial aspect of the right ramus of the mandible. A survey of literature confirms that most injuries of this kind can be treated conservatively; however careful assessment by an experienced clinician is necessary to rule out other complications. The present paper discusses the prevalence, management and complications associated with impalement injuries of the oral cavity in children.

\section{Contact Author}

\section{Dr. Sonia Goyal}

E-mail : grdr_sonia_goyal@yahoo.co.in

Key words: Pediatric, Trauma, Toothbrush

J Oral Health Comm Dent 2009;3(1):1-2

\footnotetext{
I
} njuries of the buccal mucosa, lingual soft tissue, soft palate and oropharynx are common in children especially those of pre-school age, these injuries are particularly common in toddlers, given their propensity to fall easily while carrying objects in their mouth. Although most of these injuries do not have lasting sequelae, some can have devastating neurological complications and therefore, careful assessment of the patient in the early stages of trauma is imperative. Close follow-up for upto 72 hours and parental counseling should be considered as part of their immediate care.

\section{Case Report}

A case is presented of a child who reported to the Department of Oral and Maxillofacial Surgery at ITS Centre for Dental Studies and Research, Muradnagar, Ghaziabad, U.P, with a history of fall while running with a toothbrush in the mouth, which resulted in the breaking off, of the head of the toothbrush. Initial intraoral examination did not reveal any bleeding or a wound, but on close examination just the slight end of the toothbrush was seen jutting out of the soft tissue mucosa, on the medial aspect of the right ramus of the mandible. The bristle position, up to neck of the toothbrush, could not be seen, indicating a deep impaction. The brush had penetrated the lingual mucosa engaging into the pterygomandibular space. A lateral skull radiograph was taken immediately and this revealed an adult sized tooth brush head with bristles lodged deeply medial to the right ramus of mandible in the pterygomandibular space (Fig. 1). Initially gentle force was used to remove the toothbrush, however the, the patient had severe pain and so, after administering a local anaesthetic, an incision was placed at the site of impaction. After gaining access to the embedded bristle portion, the toothbrush was removed by using an elevator, and gently dissecting out the bristles from the soft tissues (Fig. 2). The wound was then thoroughly irrigated with a dilution of 3 parts of hydrogen peroxide to 2 parts of sterile

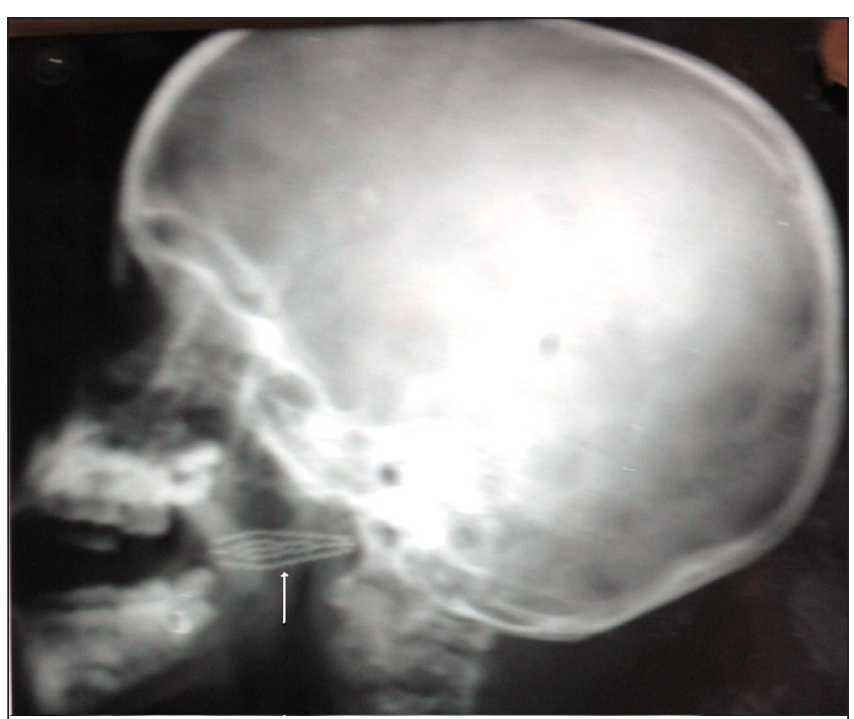

Fig. 1: Lateral skull radiograph showing the penetrated head of the toothbrush 


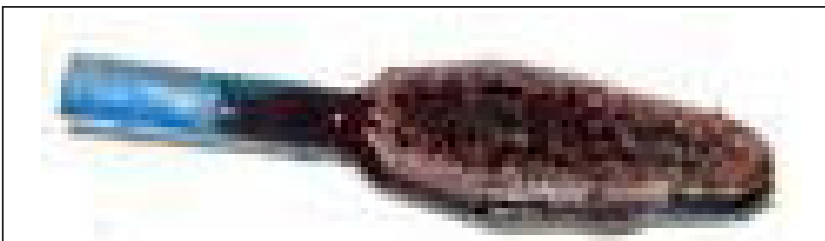

Fig. 2: Head of the toothbrush after removal

water and also saline. The wound was closed in a single layer using 3- 0 vicryl suture and no drain was deemed necessary.

The patient was discharged the same day and an antibiotic prescription consisting of oral penicillin (125mg/5ml syrup) and oral metronidazole $(100 \mathrm{mg} / 5 \mathrm{ml}$ ) for 5 days was commenced immediately (consideration being given to potential infection resulting from the presence of oral microorganisms on a used toothbrush) and injection tetanus toxoid administered.

Follow up was arranged for the next day initially, then on day 4 and again on day 7, when the sutures were removed. In the 3 years, since the injury, there has been no complication like wound sepsis.

\section{Discussion}

There are several case reports in the literature involving injuries caused by tooth brushes to the soft tissues of the oral cavity in children who have slipped and fallen down with the tooth brush inside the mouth(1). Potentially serious sequalae following an injury of this nature are not rare. These include deep neck abscess $(2,3)$, wide spread emphysemas (4), Internal Carotid Thrombosis (5) and stroke (6). The literature contains case reports where pharyngeal injuries (caused by objects held in the mouth) have resulted in thrombosis, hematomas, and even death due to trauma to the internal carotid artery. Law et al (2), described two cases of children falling with the toothbrush in their mouths, causing injuries to the soft palate and the anterior faucial pillar; the soft palate injury progressed to mediastinitis , while the faucial pillar injury progressed to a retropharyngeal abscess. Both theses patients were less than 3 years of age and had to be put on mechanically assisted ventilation for at least a week.

The current case saw the head of the toothbrush impacted on the medial aspect of the ramus, which has far more serious complications as compared to those on the lateral side (1). Despite a successful surgical retrieval, observation of the patient. for upto 72 hours has been suggested to account for the delay of some neurological complications and/or infection. According to the literature, the main site for the trauma has been the palate and lateral aspect of the ramus, rather than the the medial aspect as in the present case or in the tonsillar region as reported by Kosaki and colleagues (7).

\section{Conclusion}

In conclusion, we would like to emphasize the following points:

- It is important that these injuries are respected rather than trivialized.

- Investigations should be well carried out.

- Antibiotic therapy and tetanus toxoid should be administered.

- Children should always be supervised while brushing their teeth and should not be allowed to walk or run with any object in their mouth.

- Post trauma monitoring is essential even if the initial injury appears to be minor, as complications may not manifest immediately.

\section{THE AUTHORS}

\section{Dr. Sonia Goyal}

M.D.S

Associate professor

Deptt of Oral \& Maxillofacial Surgery

I.T.S Centre for Dental Studies and Research

Muradnagar, Ghaziabad, U.P

\section{Corresponding Author}

Dr. Sonia Goyal

\section{Dr. Suhas Godhi}

M.D.S

Professor

Deptt of Oral \& Maxillofacial Surgery

I.T.S Centre for Dental Studies and Research

Muradnagar, Ghaziabad, U.P

\section{Dr. Sandeep Goyal}

M.D.S

Professor

Deptt of orthodontics

I.T.S Centre for Dental Studies and Research

Muradnagar, Ghaziabad, U.P

\section{References}

1. Younessi OJ, Alcaino EA. Impalement injuries of the oral cavity in children: a case report and survey of the literature. International Journal of Paediatric Dentistry 2007;17:66-71.

2. Law RC, Fouque CA, Waddell $A$, et al. Lesson of the week. Penetrating intraoral traumar in children. BMJ 1997;314:50-51.

3. Chang CJ, Huang LT, Lui CC, et al. Oral wooden stick injury complicated by meningitis and brain abscess. Chang Keng I Hsuch 2002;25:266-70.

4. Rowley H, Christian J, Dennis A. Pharyngeal perforation: an easily missed finding following intra oral injury. J Accid Emerg Med 1995;12:145-46.

5. Melio FR, Jones JL, Djang WT. Internal Carotid Thrombosis in a child secondary to intra oral trauma. J Emerg Med 1996;14:42933.

6. Pearl PL. Childhood stroke following intra oral trauma. J Pediatr 1987;110:574-75.

7. Kosaki H, Nakamura N, Toriyama Y. Penetrating injuries to the oropharyx. J Laryngol Otol 1992;106:813-16. 